UDK 272-789.2(497.561Opatija)(091)

272-789.4(497.561Opatija)(091)

272-9(497.561Opatija)“15/20”

Izvorni znanstveni rad

Primljeno: 26. lipnja 2020.

Prihvaćeno za objavljivanje: 4. prosinca 2020.

\title{
OPATIJA SV. JAKOVA U OPATIJI
}

\author{
Marko MEDVED \\ Medicinski fakultet Sveučilišta u Rijeci - Katedra za humanističke \\ i društvene znanosti u medicini \\ Braće Branchetta 20, 51000 Rijeka \\ markomedved@gmail.com
}

Autor iznosi temeljne datosti iz povijesti opatije sv. Jakova, od njezinih srednjovjekovnih početaka do suvremena razdoblja. Rad donosi presjek dosadašnjih historiografskih spoznaja, stavljajući posebice naglasak na definiranje vremena i razloga benediktinskog napuštanja opatije, kao i temeljnih obilježja augustinske prisutnosti od sredine 16. do prve polovice 18. stoljeća. Autor analizira literaturu i neobjavljena vrela, iznoseći rezultate kojima zatvara neka od dosadašnjih otvorenih pitanja iz prošlosti opatije, koja je dala ime današnjem gradu Opatiji. Od 18. stoljeća opatija će biti povezana uz Riječki kolegij Družbe Isusove, a nakon toga uz arhiđakona zbornog kaptola u Rijeci. Nakon uspostave Riječke biskupije, titulu opata sv. Jakova preuzet će riječki biskup, koji je nosi do danas.

KLJUČNE RIJEČI: opatija sv. Jakova, grad Opatija, benediktinci, augustinski samostan sv. Jeronima u Rijeci, Riječki kolegij Družbe Isusove, zborni kaptol u Rijeci.

\section{Uvod}

Grad Opatija dobio je ime po opatiji sv. Jakova koja se nalazi u istoimenu parku u središtu naselja. Tijekom njezine povijesti uprava nad ovom crkvom bila je u rukama nekoliko redovničkih zajednica i drugih crkvenih struktura. Nakon srednjeg vijeka izravno je povezana s crkvenim strukturama iz grada Rijeke. Zbog fragmentiranosti ili nepostojanja arhivskog gradiva, više pitanja iz njezine prošlosti još ostaju neodgovorenima. ${ }^{1}$

\section{Benediktinska opatija sv. Jakova}

Opatija sv. Jakova ad Palum (in Palo, al Palo, de Palo, al Paolo, Abtey von St. Jakob am Stöckchen, Abbatia St. Iacobi ad Palum) prethodnica je današnjega grada Opatije, kojemu

1 Možda je to razlog zbog kojeg turistička oznaka u centru Opatije pogrešno ističe da je riječ o crkvi iz 16. stoljeća. 
je dala ime. ${ }^{2}$ Titula se povezuje uz svetog Jakova Apostola (starijeg), čije se štovanje u srednjem vijeku proširilo Europom, a njegov grob u Santiago de Composteli, na sjeveru Španjolske (Galicija), uzdigao se u najpoznatije hodočasničko odredište na kontinentu.

Smještena uz samu obalu, opatija sv. Jakova bila je na samotnom mjestu sve do 19. stoljeća, a manji broj nastambi nalazio se sjevernije, iznad današnje glavne ceste. Objašnjenja što bi značilo ad Palum nisu do danas jasna i općeprihvaćena. Kreću se od toga da je riječ o imenu mjesta u Španjolskoj u koje je Jakov došao, do toga da je riječ o štapu kojim je apostol prošao Mediteranom i koji ga razlikuje od Jakova Mlađeg, sve do toga da je riječ o iskrivljavanju izvornog imena (ad Palum, al Palo od Apollo) mjesta iz pretkršćanskog vremena na kojemu je stajao antički hram posvećen Apolonu. ${ }^{3}$

Opatija sv. Jakova u srednjem vijeku bila je bez sumnje benediktinska opatija. ${ }^{4}$ No njezina povijest nedovoljno je poznata, a više pitanja uz nju povezana i danas ostaju bez odgovora. Historiografija dosad nije dala konačan odgovor o njezinu početku, kao ni o razlozima okončanja boravka benediktinaca. S obzirom na to da se ne može točno odrediti vrijeme njezine izgradnje, ne znamo ulazi li ona u niz od stotinjak benediktinskih opatija koje su redovnici sv. Benedikta podignuli na hrvatskom prostoru od 852. godine, kada Trpimir gradi prvi benediktinski samostan u Rižinicama, do 1222. godine, kada se gradi posljednji muški benediktinski samostan sv. Jakova kod Dubrovnika. ${ }^{5}$

Amir Muzur prenosi datacije onih koji utemeljenje sv. Jakova datiraju u prvu polovicu 15. stoljeća, među kojima i Branka Fučića koji ju je neposredno nakon Drugoga svjetskog rata formulirao na temelju analize fresaka. Takva bi datacija značila da su opatiju osnovali Walseeovci, gospodari šireg područja sjevernog Jadrana u prethabsburškom razdoblju. ${ }^{6}$ Walseeovci su bili graditelji brojnih drugih crkava na širem području Liburnije: sv. Ane u Veprincu (1442.), sv. Antuna Opata u Kastvu (1453.), sv. Jurja, Ivana Krstitelja i Presvetog Trojstva u Lovranu, Majke Božje u Krasu i sv. Jurja Mučenika u Brseču. ${ }^{7}$ Juraj Batelja, referirajući se na jednu augustinsku geografsku publikaciju izdanu u Parizu u drugoj polovici 17. stoljeća, vremenu u kojem sv. Jakov drže riječki augustinci, ističe da je prvotno

2 Giovanni KOBLER, Memorie per la storia della liburnica città di Fiume, sv. 1, Rijeka, 1896., str. 163-169; Amir MUZUR, »Tko je stariji: Volosko ili Opatija?«, Časopis za povijest Zapadne Hrvatske, god. 2-3, Rijeka, 2007. - 2008., str. 15-23. O opatiji sv. Jakova na temelju crkvenog arhivskog gradiva najpoznatiji rad napisao je Luigi Maria TORCOLETTI, L'abbazia di San Giacomo al Palo, Fiume, 1944. Zadnjih godina bilježi se obnovljeni interes za tu crkvu: Berislav VALUŠEK, »Vrijeme gradnje i kasnije obnove samostana i crkve sv. Jakova u Opatiji«, Radovi Instituta za povijest umjetnosti, god. 41, Zagreb, 2017., str. 215-232; Juraj BATELJA, »Augustinski samostan u Opatiji«, Opatijske crkvene obljetnice, Zbornik radova sa znanstvenog skupa održanog u Opatiji 17. i 18. studenoga 2006. godine, Goran CRNKOVIĆ (ur.), Opatija, 2008., str. 31-43.

3 J. BATELJA, »Augustinski samostan u Opatiji«, str. 35; L. M. TORCOLETTI, L'abbazia di San Giacomo, str. 47; A. MUZUR, »Tko je stariji: Volosko ili Opatija?«, str. 17.

4 Ivan OSTOJIĆ, Benediktinci u Hrvatskoj, sv. 3, Split, 1965., str. 177-181.

5 Slavko SLIŠKOVIĆ, »Doprinos sv. Benedikta i njegova Reda oblikovanju moderne Europe«, Croatica christiana periodica, god. 34, br. 65, Zagreb, 2010., str. 169. Za opsežan pregled prisustva benediktinaca u hrvatskoj historiografskoj produkciji vidi: Tomislav GALOVIĆ - Marko TROGRLIĆ, »Benediktinci u hrvatskoj historiografiji zadnjih 50 godina (1965. - 2015.)«, Služba Božja, god. 58, br. 4, Split, 2018., str. 421-442.

6 Walseeovce kao osnivače spominje i publikacija s početka 20. stoljeća: Julius GLAX, Abbazia: ein Führer Für Curgäste, Abbazia, 1901., str. 12.

7 Vesna MUNIĆ, »Crkvica Sv. Trojice - Trojstva u Kastvu«, Zbornik Kastavštine, god. 9, Kastav, 2001., str. $17-28$. 
bila riječ o samostanu bazilijanaca (S. Iacobi Abbatia olim ad basilianos pertinens nostris ab Archiducis Austriae data.). ${ }^{8}$ U novije vrijeme povjesničar umjetnosti Berislav Valušek iznio je tezu da je opatija sv. Jakova podignuta već u 11. ili 12. stoljeću. ${ }^{9}$ S obzirom na to da se među epitetima opatije sv. Jakova, kao i nekih drugih istarskih samostana, koristio i onaj de Rosacis, derivacija od rosa (ružičnjaci, vrtovi ruža, to bi moglo upućivati na filijalni odnos sv. Jakova s velikim i starim samostanom sv. Petra u Rožacu (Furlanija), koji se nazivao de Rosazzo. ${ }^{10}$ Odbacujući mogućnost da je poput brojnih istarskih benediktinskih samostana i naš sv. Jakov nastao u 11. ili 12. stoljeću, javlja se hipoteza da je opatija utemeljena između 1422. i 1438. godine od prebjega iz furlanskog Rožaca, u trenutku kada su benediktinci te opatije, na današnjem talijansko-slovenskom graničnom području, morali napustiti svoju matičnu kuću. ${ }^{11}$

Kako bilo, benediktinci iz opatije sv. Jakova više su puta morali napuštati svoj samostan. Znamo da su to učinili sredinom 15. stoljeća. Naime, 1453. papa Nikola V. piše benediktincima sv. Mihovila u Puli o tome da se opat iz sv. Jakova kod Preluke, imenom Jakov, požalio Svetoj Stolici zahtijevajući pomoć nakon što su nepoznati počinitelji preuzeli desetinu, dobra i vlasništva samostana, među kojima liturgijske predmete iz samostana nekoć Reda sv. Benedikta. Iz Rima 17. siječnja 1453. spominje se velika krađa i potreba da se u okolnim crkvama javno upozori nepoznate počinitelje kako bi pod prijetnjom izopćenja vratili otuđeno. ${ }^{12}$ Kako je izbrojio Amir Muzur, u četrdesetim i pedesetim godinama 15. stoljeća knjiga riječkoga notara Antuna de Renno de Mutine pod nazivom Liber civilium sive notificationum opatiju sv. Jakova spomenut će više od deset puta. ${ }^{13}$

\subsection{Benediktinci napuštaju opatiju sv. Jakova zbog turskih upada}

Ne znamo kada su se, ali ni jesu li se nakon spomenutih događaja benediktinci uopće vratili u opatiju. Latinski natpis uklesan na kamenoj gredi nadvratnika glavnog ulaza crkve sv. Jakova spominje opata Šimuna, koji je obnovio crkvu 21. srpnja 1506. (1506 DIE XXI IULII SYMON ABBAS FIERI FECIT). ${ }^{14}$ Ukoliko je to bio benediktinski opat, kao što

8 Tekst o augustinskoj opatiji sv. Jakova opisuje u nastavku geografsku ubikaciju samostana ovim riječima: »Locus est ad radicem montis/ripam fluvii vulgo Fiume dicti, in Carniola, ab urbe Castua super montem sita quarante leucae distans; \& quatuor leucis ab urbis Fluminis S. Viti versus Aquilonem.« Orbis Augustinianus, Parissis, 1672., str. 240. Cit. pr. Juraj BATELJA, »Augustinski samostan u Opatiji«, str. 35.

9 B. VALUŠEK, »Vrijeme gradnje i kasnije obnove samostana i crkve sv. Jakova u Opatiji«, str. 217 i $228 . \mathrm{Na}$ temelju otkrića dvaju romaničkih naknadno zazidanih prozorskih otvora na sjevernom pročelju crkve 2006., kao i fotografije glavnog i bočnih oltara iz 1906. na kojoj se djelomično vidi unutrašnjost gotičke apside, te slike iz Vodiča po Opatiji iz 1914., autor analizira romaniku i gotiku u samostanskom kompleksu. Tvrdi kako je riječ o ruralnoj i pučkoj redovničkoj crkvici.

10 I. OSTOJIĆ, Benediktinci u Hrvatskoj, sv. 3, str. 178-179. Utemeljena koncem 11. st., opatija u Rožacu (talij. Rosazzo) doživljava procvat u 13. stoljeću. No, 1423. godine daje se u komendu, a redovnici je napuštaju.

11 A. MUZUR, »Tko je stariji: Volosko ili Opatija?«, str. 17-18.

12 Državni arhiv u Rijeci, HR-DARI-250, kutija 2. pergamene, br. 5. Usp. A. HERLJEVIĆ, »Arhiv augustinskog samostana u Rijeci«, str. 450; L. M. TORCOLETTI, L'abbazia di San Giacomo, str. 46-47.

13 Amir MUZUR, Kako se stvarala Opatija: prilog povijesti naseljavanja, grada i zdravstvenog turizma, Opatija - Rijeka, 1998., str. 22-25.

${ }_{14}$ Prenosi ga i Ivan KUKULJEVIĆ SAKCINSKI, Nadpisi sredovječni i novovjeki na crkvah, javnih i privatnih sgradah i t.d. u Hrvatskoj i Slavoniji, Zagreb, 1891., str. 207. 
tvrdi većina autora, onda je to dokaz da su benediktinci uistinu prisutni u prvim godinama 16. stoljeća. No u slučaju da je opat Šimun bio samo komendatarni opat, dakle osoba kojoj je opatija dana na upravu, onda prisutnost benediktinaca u 16. stoljeću nije potvrđena.

Analizirajući stil toga natpisa, Valušek tvrdi »da je opatijski natpis spoj ili svojevrsni kompendij utjecaja tada aktualnih pisama na našim prostorima «, $\mathrm{tj}$. karoline, beneventane $\mathrm{i}$ gotice, kao i to da bi se, uzevši u obzir središta iz kojih su se na taj prostor širili spomenuti stilovi pisanja, odnosno samostane iz nama bližih prostora, mogao odrediti samostan iz kojeg je opat Šimun došao u sv. Jakov. ${ }^{15}$

U historiografiji dosad nije općeprihvaćen razlog konačnog benediktinskog napuštanja opatije. Giovanni Kobler, prenoseći misli povjesničara Pietra Kandlera, spominje mogućnost da su benediktinci u srednjem vijeku napustili opatiju zbog kuge ili neke druge nedaće te smatra da se nakon navedenih vijesti o krađi iz sredine 15. stoljeća oni više nisu vrati1i. ${ }^{16}$ Podatak o turskim napadima kao uzroku odlaska benediktinaca iz sv. Jakova spominje autor povijesti benediktinaca u Hrvatskoj Ivan Ostojić. ${ }^{17}$ Autor Marian Fidler koncem 18. stoljeća također piše da su benediktinci napustili sv. Jakov zbog Turaka. ${ }^{18}$

Smatramo da je najuvjerljiviji razlog ponovnog benediktinskog napuštanja opatije sv. Jakova opasnost od turskih upada. To potvrđuju i neobjavljeni izvori. Ludovico Giuseppe Cimiotti-Steimberg u neobjavljenom rukopisu o povijesti Rijeke naslovljenom Publicopolitica Terrae Fluminis $S$. Viti adumbratio historice ac diplomatice illustrata, u poglavlju „O događajima kraljevske opatije sv. Jakova ad Palum, nekoć vezane za riječki augustinski samostan“" tvrdi da su benediktinci držali opatiju od njezina nastanka sve do otomanskih upada, kada bježe iz sv. Jakova u potrazi za sigurnijom lokacijom. ${ }^{19}$ Osim Cimiottija, njih izričito spominje i neistraženo augustinsko vrelo pod naslovom Protocollum conventus

15 »Također, u opatijskom natpisu možemo iščitati povijesnu situaciju tako karakterističnu za Istru; s talijanskog juga, preko Dalmacije i hrvatskih otoka, sve do Krka i Opatije dolaze utjecaji benediktinske beneventane, dok se sa sjevera, možda preko cistercitskih, dakle opet benediktinskih samostana iz Hrvatske (Senj, između ostalih) ili opatija u Stični i Kostanjevici u Sloveniji, pojavljuju utjecaji gotice. Preciznija raščlamba i uvid u komparativni materijal mogli bi nas odvesti do samostana iz kojeg je opat Šimun došao.« B. VALUŠEK, »Vrijeme gradnje i kasnije obnove samostana i crkve sv. Jakova u Opatiji«, str. 221.

16 G. KOBLER, Memorie per la storia, sv. 1, str. 164.

17 I. OSTOJIĆ, Benediktinci u Hrvatskoj, sv. 3, str. 180.

${ }_{18}$ Poznatiji kao pater Marian, kojega kao autora djela Austria Sacra Kobler više puta citira, piše: »Pertinebat olim ad religiosos e divi Benedicti familia, qui frequentibus Turcarum ad hoc litus maritinum excursionibus territi eandem prorsum deseruerunt.« M. FIDLER, Geschichte der ganzen österreichischen, sv. 5, str. 421. Vidi i str. 162.

${ }^{19}$ U šestom poglavlju De incolis et re sacra, pododsjeku B De re sacra, broj 21, pod naslovom Vicessitudines abbatiae realis s. Iacobi ad Palum, olim ad patres Augustinianos conventus Fluminensis pertinentis, Cimiotti piše: »Ab origine abbatiam hanc PP benedictinos tenuisse ferunt, donec a Turcis oras illas saepius infestantibus in fugam acti, quietatem securitatemque secum alibi locorum quaerentes, domicilium hocce penitus defervissent. Cessato subin hostili periculo eamdem abbatiam episcopi Segnienses in meliorem mensae dotationem impetrarunt, et usque proinde est ad annum 1555 eum possederunt, quod post obitum episcopi Iohannis Siskovich ordini patrorum eremitarum s. Augustini conventus Fluminensis, ut paulo prius meminimus, obtigit, qui in eiusdem possessoris usque annum abbatia haec in plurium adhuc dominorum potestatem decursu subsequentium 15 annorum Seminarii S. Ignatii et Collegiati capituli Fluminensis concessisset pignanter, postremum eamdem anno 1750 collegio Fluminensi Societatis Iesu pro $2500 \mathrm{fl}$. vevumdedit Iohanni Collarich ec ordine eremitarum s. Pauli cum praehabito inful usu, confirmante Pontifice Clemente XII ab alienata fuit..." Ludovico Giuseppe CIMIOTTI-STEINBERG, Publico-politica Terrae Fluminis S. Viti adumbratio historice ac diplomatice illustrata u Sveučilišna knjižnica u Rijeci, Fond Rara, inkunabule i rukopisi, A.189, I. 
Fluminensis Ordinis eremitarum s. patri Augustini ad s. Hieronymum, koje navodi otomanske upade u okolici Rijeke 1522., 1527, 1528 i 1533..$^{20}$ Uzevši u obzir sve navedeno, možemo ustvrditi, ispravljajući Koblerove teze, da su se benediktinci vratili nakon sredine 15. stoljeća i da su u prvoj polovici 16. stoljeća ponovno morali napustiti opatiju zbog otomanske opasnosti.

Turska opasnost spominje se i dva stoljeća kasnije. Nesigurnost zbog mogućih turskih upada u prvoj polovici 18. stoljeća kao argument za prodaju opatije, među više drugih, spominje se i u molbi koju augustinci upućuju rimskoj Kongregaciji za redovnike, koja će 19. prosinca 1721. odgovoriti dozvoljavajući prodaju. ${ }^{21}$ Doduše, čini nam se da nije vjerojatno da je u trećem desetljeću 18. stoljeća takvih upada još moglo biti na tom području, ali je spomen na njih nakon oslobođenja Like i Krbave tada vjerojatno još bio živ, pa su i to smatrali legitimnim i uvjerljivim argumentom kako bi ishodovali dozvolu za prodaju. Mislimo da su augustince na prodaju sv. Jakova naveli financijski razlozi povezani uz izgradnju novog krila riječkog samostana sv. Jeronima. ${ }^{22}$

Dakle, dok nam datacija dolaska benediktinaca ostaje još uvijek nepoznata, okolnosti njihova napuštanja današnje Opatije su jasniji. Otomanski upadi uzrok su benediktinskom napuštanju sv. Jakova, a to opetovano napuštanje dogodilo se vjerojatno oko 1522. godine. Uza sve to, valja podsjetiti na to da je i prije toga benediktinska prisutnost u sv. Jakovu bila nekontinuirana.

\section{Razdoblje komendatarnih opata}

Kobler navodi spis riječkog bilježnika od 8. svibnja 1449., koji u sv. Jakovu spominje opata Radmana. ${ }^{23}$ Njegov nasljednik je Jakov, koji se spominje u pismu pape Nikole V. od 17. siječnja 1453. godine. Kobler je naklonjen povezivanju nastanka sv. Jakova s mnogobrojnim istarskim benediktinskim samostanima osnovanima u srednjem vijeku. On smatra da ni redovnik Jakov, koji se obraća papi Nikoli sredinom 15. stoljeća, nije više bio pripadnik benediktinske zajednice koja živi u sv. Jakovu, već osoba kojoj je samostan dodijeljen kao nadarbina, dakle komendatarni opat. Po njegovu su mišljenju, prvotni benediktinci odavno su napustili sv. Jakov, zbog čega su dobra o kojima je riječ 1453. godine bila otuđena. ${ }^{24}$ Pozivajući se na spis iz 1540. godine iz arhiva riječkog arhiđakona, Kobler piše kako je nakon oduzimanja opatije Ivanu Bekariću (komendatarnom opatu) car Maksimilijan I. opatiju dao svećeniku Nikoli Donatoviću. Potonjeg je izbacio kapetan Rijeke i Kastva

\footnotetext{
${ }^{20}$ HR-DARI-250, kut. 1, Protocollum, N. 27, str. 6-7. Benzonijeva kratka povijest augustinskog samostana sv. Jeronima u Rijeci, rukopis iz sredine 18. st. sačuvan u Beču, navodi samo 1522. godinu. Historia concernens conventum Fluminensem Ordinis eremitarum s. patris Augustini ad divum Hieronymum, Österreichische Nationalbibliothek, Wien (=ÖNB, Austrijska nacionalna knjižnica u Beču), Handschrift 10214p, ff. 11rv.

21 »Essendo quella poco sicura in caso di qualche scorrerie de Turchi, ... et che più lontana dalla giurisdizione della città, in luogo si può dire deserto vicino al mare...« Nadbiskupijski arhiv Rijeka, fond Zborni kaptol i Arhiđakon, (=NAR), fond Zborni kaptol i Arhiđakonat, Odgovor rimske Kongregacije za redovnike, 19. prosinca 1721., kutija AX.

22 Usp. Protocollum, str. 28.

${ }^{23}$ G. KOBLER, Memorie, sv. 1, str. 164.

24 Isto.
} 
Ivan Rauber pa ju je dobio Toma Akčić (Achcich). Pozivajući se na spis koji to tvrdi, Kobler istodobno izražava sumnju u njegovu autentičnost jer odmah zapisuje kako tih godina Ivan Rauber nije bio kapetan niti je Maksimilijan tada bio na životu. Riječki povjesničar Kobler prihvaća da je Toma Akčić bio opatom i da je 1544. godine još bio na službi. Potonji je 1538., uz godišnji iznos od 12 lira, Nikoli Rosoviću dao u najam neobrađeno dobro samostana, a naredne godine i kuću koju je opatija imala u gradu Rijeci, uz godišnji iznos od 16 lira. Sve je to potvrdio Ferdinand I. aktima iz 1545. i 1553. godine. Potom je opatiju Ferdinand I. dao imenovanom senjskom biskupu Franji Živkoviću, koji je tu nadarbinu uživao od 3. ožujka 1552. godine do svoje smrti 1560. godine. ${ }^{25}$

\section{Riječki augustinci u opatiji sv. Jakova}

Augustinci, koji se u Ljubljani nalaze od početka 14. stoljeća, pedesetih godina 16. stoljeća prisiljeni su zbog širenja reformacije i pretvaranja njihova samostana u hospital napustiti svoje sjedište. ${ }^{26}$ Nakon što su 1555. izgubili samostan, slovenski augustinci nalaze utočište kod subraće iz Rijeke. ${ }^{27}$ Zbog dolaska slovenskih redovnika Ferdinand je poveljom od 29. listopada 1555. opatiju sv. Jakova trajno dao riječkim augustincima. Doduše opatija je već bila dodijeljena Franji Živkoviću, izabranom senjskom biskupu, kojem je do smrti dozvoljeno njezino uživanje. Augustincima je opatija dodijeljena na ime naknade (recompensatione) za izgubljeni samostan u Ljubljani. ${ }^{28}$ Ona je tada već više godina bila napuštena. ${ }^{29} \mathrm{U}$ vidu troškova novopridošlih slovenskih redovnika, augustincima iz Rijeke od prihoda riječke carine udijeljeno je 125 forinti godišnje, a oslobođeni su plaćanja daće za uvoz i prodaju vina i žita s opatijskih posjeda. ${ }^{30}$

Jedan od dvaju sačuvanih kartulara augustinaca riječkog sv. Jeronima odnosi se na opatiju sv. Jakova. Kartular naslovljen Transumpta privilegiorum fundationalium, aliorumque instrumentorum. ocumentorum memorabilium authentica conventiis s. Hieronymi Fluminensi ord. erem. S. Augustini et abbatiae S. Iacobi a Palo, sačuvan u Državnom arhivu u Rijeci, donosi više vijesti o augustinskoj upravi nad opatijom. ${ }^{31}$ Spominje se pravno

\footnotetext{
25 Isto, str. 165.

26 Vidi J. BATELJA, »Augustinski samostan u Opatiji«, str. 36-37.

${ }^{27} \mathrm{O}$ riječkom augustinskom samostanu vidi nove radove: Ozren KOSANOVIĆ, »Inventar pokretnih dobara augustinskog samostana sv. Jeronima u Rijeci iz 1523. godine«, Problemi sjevernog Jadrana, god. 17, Rijeka, 2018., str. 23-33; Marko MEDVED, »Incuria et vandalismus - sudbina arhiva augustinskog samostana sv. Jeronima u Rijeci«, Arhivski vjesnik, god. 62, Zagreb, 2019., str. 85-105; M. MEDVED, »Datacija izgradnje augustinskog samostana i crkve sv. Jeronima u Rijeci«, Croatica christiana periodica, god. 43, br. 84, Zagreb, 2019., str. 21-38; M. MEDVED, »Nepoznati hospital augustinaca pustinjaka riječkog sv. Jeronima. Prilog povijesti medicine u Rijeci«, Acta medico-historica Adriatica, god. 17, br. 2, Rijeka, 2019. str. 195-212; M. MEDVED, »Augustinci pustinjaci riječkog sv. Jeronima u 15. stoljeću«, Radovi Zavoda za hrvatsku povijest Filozofskog fakulteta Sveučilišta u Zagrebu, god. 51, br. 2, Zagreb, 2019., str. 159-176.

${ }_{28}$ Kobler spominje 29. listopada 1555. kao datum Ferdinandova ustupanja opatije augustincima, ali faktično preuzimanje opatije učinjeno je već sredinom svibnja te godine.

29 M. FIDLER, Geschichte der ganzen österreichischen, klösterlichen und weltlichen Klesirey beyderley Geschlechtnes, sv. 5, str. 162 i 421.

${ }^{30}$ G. KOBLER, Memorie, sv. 1, str. 165. Kopija Ferdinandove povelje nalazi se među spisima riječkih augustinaca u ovjerovljenom prijepisu koji je sv. Jeronimu uputio Kaptol u Ljubljani spisom od 18. ožujka 1583.

${ }_{31}$ Prijepis Ferdinandove odluke u Transumpta privilegiorum na str. 101.
} 
preuzimanje sv. Jakova 13. svibnja 1555. godine. Činu preuzimanja nazočne su civilne vlasti Kranjske, a samo uvođenje u posjed riječkoga augustinskog priora Ivana Primožića predvodio je opat Živković. ${ }^{32}$ Tako je povijest bivšega benediktinskog samostana sv. Jakova u današnjoj Opatiji u naredna dva stoljeća ostala usko povezana uz Rijeku.

Na kraju vijesti o dobivanju opatije Protocollum conventus riječkog augustinskog samostana spominje da je sv. Jakov nekoć pripadao benediktincima (abbatia olim fuerit patrorum benedictinorum). ${ }^{33}$ Protocollum conventus također donosi razne vijesti o opatiji sv. Jakova. Vrelo spominje stari urbar opatije (ex antiquo registro seu urbario abbatiae), navodeći prava redovnika, među kojima i pravo ribolova u Preluki. ${ }^{34}$ General augustinskog reda postavio je 17. travnja 1562. godine na čelo opatije sv. Jakova, riječkog redovnika Jeronima. Odredio mu je da sa sobom uzme još jednog pomoćnika i da u sv. Jakovu živi po redovničkim pravilima. ${ }^{35}$

Sredinom prve polovice 17. stoljeća slovenski se augustinci vraćaju u Ljubljanu nakon sedamdeset godina izbivanja. Tada se javlja spor između riječkih i ljubljanskih redovnika o vlasništvu nad sv. Jakovom, o čemu presuđuju središnje vlasti reda u korist redovnika u Sv. Jeronimu. ${ }^{36}$

Augustinci su preuzeli opatiju sv. Jakova u vrijeme kada ona nije bila u zavidnom materijalnom stanju. Nije pretjerano reći da se i prije i poslije toga radilo o siromašnoj opatiji. Takvom će ostati i tijekom boravka augustinaca, a valja napomenuti da augustinska uprava sv. Jakovom uključuje i teško razdoblje poput Uskočkoga rata (1615. - 1617.), koji je doveo do sloma istarskog gospodarstva, a u kojemu su obližnja Ćićarija i Kras bili izloženi kontinuiranim napadima i u kojem se jako uskočko uporište nalazilo u obližnjim Munama. ${ }^{37}$ Sve to, kao i Tridesetogodišnji rat, koji je uslijedio neposredno nakon toga, negativno su se odrazili na uvjete života $u$ opatiji.

Augustinci su u više navrata ulagali financijska sredstva u opatiju. Godine 1577. u dvorištu samostana izgrađena je cisterna, bunar. ${ }^{38}$ Doznajemo i to da su sredstva augustinskog priora Brna, Riječanina Jurja Gladića 1663. godine uložena u opatiju sv. Jakova. ${ }^{39}$ Nemamo mnogo izvora za rekonstruiranje okolnosti augustinskog života u sv. Jakovu. Preuzimanje opatije označilo je i početak naseljavanja civilnoga stanovništva. Kako piše Muzur, velika dobra u posjedu augustinaca potakla su stanovnike Kastavštine i Veprinca na ulaženje u kolonatske

\footnotetext{
32 Zapisnik augustinskog preuzimanja opatije 1555., sastavljenog u prisutnosti tršćanskog notara Maria de Argentisa i riječkoga gradskog kancelara nalazi se u Transumpta privilegiorum, str. 113-117.

33 Protocollum, str. 28.

${ }^{34}$ HR-DARI-250, kutija 2, pergamene, u inventaru br. 32; Protocollum, N. 119, str. 26-28. Vidi i inventar prigodom prodaje opatije isusovcima, kutija 6, Posjedi izvan Rijeke, br. 2.

35 »Fratrem Hieronymum Fluminensem moderatorem abbatiae sancti Iacobi ad Palum modum beneplacitum instituimus, tanquam in membro provinciae, qui secum sociu duceret, admonentes illum ad religiose vivendum.« Arhiv generalnog priora augustinskoga reda, Rim (=AGA), Dd, 29, f. 206r.

${ }_{36} \mathrm{Za}$ razliku od Koblera (G. KOBLER, Memorie, sv. I, str. 166), koji spominje presudu ljubljanskog i pićanskog biskupa o sporu dvaju samostana, smatramo da su biskupi samo prenijeli odluku središnjih vlasti reda, kao što proizlazi iz arhivskog gradiva centralnog arhiva augustinskog reda u Rimu. AGA, Dd 69, f. $112 \mathrm{v}$.

${ }^{37}$ Usp. Miroslav BERTOŠA, Jedna zemlja, jedan rat: Istra 1615./1618., Pula, 1986.

38 Protocollum, N. 195, str. 43.

39 Protocollum, N. 209, str. 45.
} 
odnose s augustincima sv. Jakova. ${ }^{40}$ Dosad neistražena augustinska vrela Protocollum conventus i Transumpta donose brojne ugovore augustinaca s lokalnim stanovništvom o najmu zemljišta i popis podavanja. Doznajemo da se s kolonima najčešće sklapao ugovor koji je uključivao davanje četvrtine plodova. Protocollum conventus riječkog sv. Jeronima donosi podrobne podatke o plodovima koje je opatija sv. Jakova dobivala od seljaka na samom početku 18. stoljeća. U tekstu podnaslovljenom »Vinogradi u vlasništvu samostana« spominju se dva vinograda između Voloskog, Veprinca i morske obale iz kojih opatija prima četvrtinu vina, ulja i žitarica. ${ }^{41}$ Godine 1704. opatija dobiva 160 urni vina, »skoro ništa« žitarica, 6 centenariusa ulja. Usto je od vinograda nad kojim je udovica Valentini dobila hipoteku od 300 libara, opatija 1704. godine primila polovicu vina, ulja i drugih plodova. ${ }^{42}$

Nema dvojbe o tome da su augustincima u upravljanju opatijom sv. Jakova najviše problema zadavali obližnji Kastavci, s kojima su tijekom 170 godina uprave bili u napetim odnosima. Dvadesetak godina nakon preuzimanja opatije riječki prior Ivan Klobučarić požalio se 1578. godine nadvojvodi Karlu da kapetani Rijeke i Kastva sebi pridržavaju ekskluzivno pravo ribarenja u Preluki, a da Kastavci vladaju nad kolonima u Opatiji. ${ }^{43}$ Transumpta privilegiorum donosi presudu protiv Kastavaca koji su povrijedili azil opatije sv. Jakova te su silom odveli ubojicu koji se tamo sklonio pobjegavši iz pritvora 1558 . godine. ${ }^{44}$ Učestale su žalbe o jurisdikciji nad kolonima, o ometanju obrađivanja zemlje i nepoštovanju augustinskog prava na prvolov na Preluci, a bilo je i fizičkih sukoba. U proljeće 1584. godine izbili su nemiri između Kastavaca i augustinske opatije, kojima su se morale pozabaviti i civilne vlasti. Kobler opisuje konkretan događaj iz 1579., kada je na blagdan sv. Jakova (25. srpnja) došlo do sukoba riječkih hodočasnika koji su na taj dan tradicionalno pješačili do opatije, nakon čega taj običaj prestaje i građani Rijeke odlaze samo do Rečica (lokacije pored bivše tvornice Torpedo). ${ }^{45} \mathrm{~S}$ Kastavcima je povezana i presuda iz 1679. godine o tome da svi oni koji imaju vinograde na području opatije sv. Jakova ne mogu bez prethodne dozvole redovnika brati lozu.

Zaključci kapitula Štajersko-koruške i Austrijske provincije ne spominju redovito popunjavanje opatije. ${ }^{46}$ Nije jasno znači li to da augustinci nisu kontinuirano upućivali redov-

\footnotetext{
40 »Dolaskom augustinaca u posjed opatije stvari su se očito stubokom izmijenile. Nakon početnih natezanja, augustinci su ipak, za mir u kući, priznali onaj ritual darivanja stražara volovljim mesom, hljepčićima i vinom, pa i neke časti kapetanu, sucima i župniku iz Kastva, ali pakt opata s Kastavcima jednom je zauvijek i nepovratno narušen, a prekinuta je i stoljetna blokada naseljavanja koju su, bez sumnje, benediktinski monasi u skladu s pravilima svoga reda podržavali. Kako je okolno zemljište bilo preveliko da bi ga stanovnici samostana sami obrađivali, vjerovati je, međutim, da su kastavski (možda i veprinački) kmetovi ulazili povremeno u kolonatske odnose s opatijom. Tisuću petsto pedesete-šezdesete bi, dakle, trebalo uzeti godinama otvaranja sezone prave kolonizacije na području koje je nama danas znano kao Opatija.«A. MUZUR, »Tko je stariji: Volosko ili Opatija?«, str. 19; ISTI, Kako se stvarala Opatija, str. 39-40.

${ }^{41}$ Protocollum, N. 212, str. 45.

42 Protocollum, str. 53.

${ }^{43}$ G. KOBLER, Memorie, 1, str. 166.

${ }^{44}$ Transumpta privilegiorum, str. 147. Usp. A. HERLJEVIĆ, »Arhiv augustinskog samostana u Rijeci«, str. 448.

45 G. KOBLER, Memorie, 1, str. 166.

${ }^{46}$ Povjesničar srednjoeuropskih augustinaca John J. Gavigan to ovako izriče: »For some time, no individual priest had been assigned to the abbey of San Giacomo al Palo...« John J. GAVIGAN, The Austro-Hungarian province of the Augustinian Friars 1646-1820, sv. 2, Development, Studies, Baroque Brilliance, Roma, 1976., str. 170.
} 
nike i opate u sv. Jakov. Karlo Ivanković spominje se kao upravitelj sv. Jakova 9. travnja 1647., 30. svibnja 1671. i 9. travnja 1674. godine. Lovro Tonzić izabran je na provincijalnom kapitulu 1676. godine. Nikola Benedetti kao upravitelj spominje se 1682. i 1692. godine, istodobno sa službom zamjenika priora sv. Jeronima u Rijeci. Joakim Spigliati opat je 1686., 1688. i 1689. godine. ${ }^{47}$ Neizravna potvrda o nekontinuiranom boravku augustinaca u sv. Jakovu je i vijest iz 1692. godine, kada provincijalni kapitul austrijskih augustinaca, određujući redovnika Nikolu Benedettija za taj samostan, napominje da mora redovito boraviti u njemu kako bi na taj način zaštitio augustinska prava na upravu tom opatijom. ${ }^{48}$ Benedettija 1695. godine zamjenjuje Aleksandar Sambsa. ${ }^{49}$ Potonjem 1701. godine kao upravitelju opatije sv. Jakova definitorij Austrijske augustinske provincije, uz već postojećih četiri koje prima iz sv. Jeronima, dodjeljuje još dva skuda, uz izričitu opasku da upravu vrši vrijedno te da uredno posadi vinograde. ${ }^{50} \mathrm{~S}$ provincijskog kapitula održanog u Beču od 1. do 5. svibnja 1716. godine doznajemo da je dugogodišnji upravitelj opatije sv. Jakova Sambsa podnio ostavku, a na njegovo mjesto postavljen je Ivan Krstitelj Barčić. ${ }^{51} \mathrm{Na}$ kapitulu u Grazu koncem travnja 1719. upravitelj sv. Jakova je Ivan Krstitelj Barčić. Prior sv. Jeronima nezadovoljan je njegovom upravom jer zaključak kapitula naređuje upravitelju opatije sv. Jakova da ne ulazi u sklapanje novih poslovnih aranžmana bez prethodne dozvole riječkog priora. To je potvrda da u sv. Jeronimu nisu prihvaćali autonomiju koju su si samovoljno uzimali upravitelji opatije, zbog čega su iz sv. Jeronima zatražili i dobili odredbu najvišeg tijela provincije. ${ }^{52}$ Iz zapisa s kapitula koncem travnja 1722. godine doznajemo da je upravitelj opatije sv. Jakova Augustin Zanchi. ${ }^{53}$

\subsection{Augustinci prodaju opatiju sv. Jakova zbog financiranja radova na obnovi riječkog samostana i crkve}

Rimska Kongregacija za redovnike 19. prosinca 1721. dopustila je riječkom augustinskom samostanu prodaju opatije sv. Jakova. U njezinu odgovoru citira se dio molbe koju su prije toga u svome zahtjevu iznijeli riječki augustinci i iz koje doznajemo da je daljnji ostanak opatije u okvirima riječkog samostana za njih bio veliki financijski teret i da bi od njezine prodaje i kamata na ta sredstva, kako tvrde, u jednoj godini zaradili više od onoga što su inače dobivali u tri godine. Spis donosi i podatak o tome da je u to vrijeme kraj oko opatije sv. Jakova skoro posve pust, da je ostanak jednog redovnika koji ondje živi za njega neugodan, što zbog štete za zdravlje jer se opatija nalazila u vrlo lošem stanju, što zbog sigurnosti s obzirom na opasnost od upada Turaka. ${ }^{54}$

\footnotetext{
${ }^{47}$ Podatke o godinama uprave opata Ivankovića, Tonzića, Benedettija i Spigliatija preuzimamo iz: Juraj BATELJA, »Augustinski samostan u Opatiji «, str. 41.

48 ÖNB, 8461, f. 57r.

49 ÖNB, 8461, f. 57r.

${ }_{50}$ ÖNB, 8461, f. 78v. J. J. GAVIGAN, Development, Studies, Baroque Brilliance, str. 251.

51 ÖNB, 8461, f. 146v-147r. J. J. GAVIGAN, Development, Studies, Baroque Brilliance, str. 280.

${ }_{52}$ ÖNB, 8461, f. 161v. Usp. J. J. GAVIGAN, Development, Studies, Baroque Brilliance, str. 288.

53 J. J. GAVIGAN, Development, Studies, Baroque Brilliance, str. 297.

${ }^{54}$ U odgovoru rimske Kongregacije upućenom riječkom zbornom kaptolu među ostalim se tvrdi: »Ove continuamente deve essere di permanenza un religioso con grave pericolo della sua salute, et esterminio del convento, essendo la casa o sii residenza del medesmo tutta cadente; così che per rifarla e ridurla in stato di
} 
Riječki su augustinci 1722. godine zatražili carsku dozvolu da im se dopusti prodaja opatije. Zahtjev, koji potpisuju provincijal Hijacint Maristoni Riječanin i riječki prior Ivan Krstitelj Barčić, potrebu prodaje obrazlaže sličnim argumentima navedenim u korespondenciji s Rimom. Riječki augustinci pišu da im je opatija više na štetu nego na korist, da je daleko od Rijeke, da se nalazi na pustom i nesigurnom kraju, osobito u slučaju provala turskih četa, da je redovnik koji ondje boravi u velikom strahu za vlastiti život i za opatijska dobra ionako siromašnog samostana, da obnova opatije zahtijeva sredstva koja sv. Jeronim nema te da bi se za njezinu obnovu trebalo odreći odveć velikih sredstava. ${ }^{55}$

Augustinci prodaju opatiju Družbi Isusovoj, koja u Rijeci drži Kolegij, ali i opatiji obližnju Kastavsku gospoštiju. Dosad je povjesničarima bio nepoznat pravi razlog zbog kojeg je opatija prešla iz augustinskih u isusovačke ruke. Motivacija za prodaju opatije sv. Jakova nalazi se u velikom građevinskom zahvatu koji su riječki augustinci pokrenuli sredinom dvadesetih godina 18. stoljeća. Oni su 1726. godine položili kamen temeljac velikog preuređenja samostanskog kompleksa. Potvrdu o tome da je prodaja sv. Jakova vezana uz potrebu osiguranja financijskih sredstava za radove većeg opsega u Rijeci nalazimo u vrelu Protocollum conventus. Naime, u podužem tekstu oko dobivanja opatije sv. Jakova 1555., nakon spominjanja prodaje opatije sv. Jakova isusovcima, augustinski zapisivač objašnjava da je to učinjeno kako bi se namakla sredstva za obnovu samostanske crkve u Rijeci: pro fabrica novae ecclesiae $1768 .{ }^{56}$ Iako se spominje izgradnja nove crkve, skloniji smo vjerovati da se pod time misli na radove na cjelokupnom augustinskom samostanskom kompleksu, započete upravo sredinom dvadesetih godina, neposredno nakon prodaje opatije i završene u drugoj polovici 18. stoljeća s proširenjem crkve.

Augustinci su opatiju sv. Jakova držali do 1723. godine, kada je ugovorom od 10. travnja za 2650 forinti prodana riječkim isusovcima. ${ }^{57} \mathrm{Na}$ kapitulu Austrijske augustinske provincije od 26. travnja 1725. doznajemo da su riječki augustinci, s dozvolom Habsburgovaca i rimske Kongregacije, prodali opatiju sv. Jakova za 2500 forinti. $^{58}$

\section{Sudbina opatije nakon augustinske uprave}

Isusovci su opatiju sv. Jakova držali samo nekoliko godina, jer je već 26. ožujka 1735. za 3000 forinti prodaju Ivanu Čikulinu, feudalcu iz Međimurja. On ju je najprije ustupio Ivanu Kolariću iz pavlinskog samostana u Crikvenici da bi je već 26. travnja 1738. poklonio zbornoj crkvi Uznesenja Marijina u Rijeci. Nakon što se Kolarić 11. prosinca 1745. odrekao opatije, riječki je kaptol preuzeo puno vlasništvo, uz obvezu godišnje mise. No već 1748. godine kanonici se žale na kastavskog civilnog kancelara, pa je 1750. godine za 2500 forinti prodaju isusovačkom kolegiju, s obzirom na to da su kao vlasnici Kastavske

\footnotetext{
migloramento dovrebbe questo espropriarsi di propria fondazione in grave suo danno e detrimento essendo quella poco sicura in caso di qualche scorrerie de Turchi, ... et che più lontana dalla giurisdizione della città, in luogo si può dire deserto vicino al mare. « NAR, fond Zborni kaptol i Arhiđakonat, Odgovor rimske Kongregacije za redovnike, 19. prosinca 1721., kutija AX.

${ }_{55}$ Navedeni zahtjev prenosi J. BATELJA, »Augustinski samostan u Opatiji«, str. 38.

56 Protocollum, str. 28.

${ }^{57}$ G. KOBLER, Memorie, 1, str. 168.

58 ÖNB, 8461, ff. 202v-203r.
} 
gospoštije, jezuiti lakše mogli izaći na kraj s tim napetostima. Do ukinuća Družbe Isusove dolazi 1773. godine, a opatija je godinu dana kasnije trajno dana riječkom arhiđakonu, najvišoj službi zbornog kaptola. Kobler zapisuje da su sredinom 19. stoljeća prihodi toliko mali tako da riječki arhiđakon kao opat sv. Jakova jedva uspijeva plaćati kapelana na službi u opatiji.

Nakon prodaje opatije isusovcima čini se da je Družba Isusova opatijske arhivske spise povukla u Kastav. O tome doznajemo iz jednog sastanka riječkog zbornog kaptola koji na sjednici 1724. godine spominje postupak pred kapitanatskim sudom u Kastvu oko povrata otuđenih spisa iz sv. Jakova, koji se izravno tiču toga samostana. ${ }^{59}$

\subsection{Riječki arhiđakoni opati sv. Jakova}

Običaj riječkih arhiđakona da nose mitru proizlazi iz spomenutog preuzimanja opatije sv. Jakova. Početke možemo vidjeti još u 1735. godini kada pavlin Ivan Kolarić od Čikulina preuzima opatiju sv. Jakova, nakon čega se potpisuje kao mitronosni opat sv. Jakova (abbas infulatus s. Iacobi ad Palum). ${ }^{60}$ Riječki arhiđakoni opati sv. Jakova bili su redom: Franjo pl. Svilokossi Jurković, Toma Martin pl. Peri, Josip Franjo Spingaroli, Franjo Livak, Josip Wissner, Ivan Fiamin (vjerojatno jedini opat sv. Jakova rođen na području današnje Opatije), Kajetan Bedini, Nikola Fulvi i Ignacije Martinec. ${ }^{61}$

Do promjene dolazi osnutkom samostalne dijeceze u Rijeci tijekom talijanske uprave. Naime, Riječka biskupija osnovana je bulom pape Pija XI. Supremum pastorale munus od 25. travnja 1925. godine. Uspostava biskupije značila je i dokidanje drevnog zbornog kaptola i uspostavu stolnog (katedralnog) kaptola pri sv. Vidu. U papinoj buli osnutka biskupije određeno je da riječki biskup preuzima titulu opata sv. Jakova, koju je dotad nosio arhiđakon zbornog kaptola Uznesenja Blažene Djevice Marije. ${ }^{62}$ U papinoj buli iz 1925. stoji: »Episcopo praeterea Fluminensi facultatem facimus assumendi titulum quoque Abbatis sancti Iacobi de Abbatia, quo hactenus Praepositus Capituli collegialis ecclesiae Beatae Mariae Virginis in Caelum Assumptae condecorabatur. ${ }^{63}$ Prvi riječki biskup Isidoro Sain sastavio je i vlastoručno potpisao izjavu koja je eksplicitno utvrdila utrnuće zbornog kaptola na dan 28. ožujka 1927., nakon prijelaza kanonika Ivana Kukanića i Ignacija Martinca (zadnjega riječkog arhiđakona) u Senjsko-modrušku biskupiju. Stoga taj datum valja smatrati datumom utrnuća starodrevnog riječkog zbornog kaptola. ${ }^{64}$

Godine 1926. uspostavljena je župa u Opatiji, odvojivši teritorij dotadašnje kapelanije od matične župe Volosko, te je povjerena benediktincima. Name, benediktinci olivetanske kongregacije od početka 20. stoljeće nalaze se u Opatiji, gdje grade samostan. Na brdu nadomak stare opatije sv. Jakova gradi se veća crkva s titulom Navještenja Marijina, po-

\footnotetext{
59 »Coram foro Capitaniali Castuani Causam pro recuperandis omnibus et singulis scripturis Abbatiam S. Iacobi ad Pallum concernentibus. « NAR, fond Zborni kaptol i Arhiđakonat, Acta Capitularia ab Anno 1727, f. 44v.

${ }^{60}$ G. KOBLER, Memorie, 1, str. 168.

${ }^{61}$ L. M. TORCOLETTI, L'abbazia di San Giacomo al Palo, str. 54-66. Usp. G. KOBLER, Memorie, 1, str. 89.

${ }^{62}$ Usp. Franjo VELČIĆ, »Naslov opata sv. Jakova«, Opatijske visoke obljetnice, str. 57-60.

${ }_{63}$ Marko MEDVED, Riječka Crkva u razdoblju fašizma. Nastanak biskupije i prvi talijanski upravitelji, Zagreb, 2015., str. 337.

${ }^{64}$ Usp. Isto, str. 336-338, 359-368.
} 
svećena 1932. godine..$^{65}$ Tijekom episkopata riječkog biskupa Uga Camozza opatija sv. Jakova je proširena. ${ }^{66}$ Nakon što su hrvatski benediktinci otišli na Ćokovac (Tkon na Pašmanu), godine 1961. dolazi Družba Isusova. ${ }^{67}$ Župa u Opatiji od 2007. nosi titulu sv. Jakova.

\section{Zaključak}

Počeci opatije sv. Jakova u gradu Opatiji, koji je po njoj dobio ime, obavijeni su u tamu zbog oskudnih arhivskih vrela. Iako se ne zna točno vrijeme dolaska benediktinaca, registrirana je njihova prisutnost u razvijenu srednjem vijeku. Očito je da su morali napuštati opatiju u više navrata, a zbog otomanske opasnosti trajno je ostavljaju u prvoj polovici 16. stoljeća, nakon čega je davana u komendu. Od 1555. do 1723. opatija se nalazi pod upravom augustinaca riječkog sv. Jeronima, kojima su je austrijske vlasti dale zbog prihvaćanja izbjeglih ljubljanskih augustinaca u bijegu od reformacije. Potom je preuzima isusovački Riječki kolegij, a nakon toga zborni kaptol Uznesenja Marijina u Rijeci, čiji arhiđakon zbog toga nosi titulu opata sv. Jakova. Nakon gašenja zbornog kaptola uslijed uspostave Riječke biskupije, titulu opata sv. Jakova preuzet će riječki biskup, koji je nosi do danas i nakon što je dijeceza uzdignuta na razinu nadbiskupije.

\section{SUMMARY}

\section{ABBEY OF ST JAMES IN OPATIJA}

Author delivers general history of the Abbey of St James, from its beginnings in the Middle Ages up to contemporary times. Based on the information from the relevant historiographical literature, author emphasizes discussion about the time and reasons when Benedictines have left the Abbey, as well as the importance of Augustinians in the period between the mid-sixteenth and mid-eighteenth century. Analysis of the relevant literature and archival unpublished sources enabled author to propose answers to some up-to-now unanswered questions regarding the history of the Abbey after which is named Town of Opatija. From the eighteenth century this Abbey was organizationally subjected to the Jesuit College in Rijeka, and later to the archdeacon of Collegiate Chapter at Rijeka. After the Diocese of Rijeka was founded the title of the abbot of St Jaes became a part of the title of the Bishop of Rijeka.

KEY WORDS: Abby of St James, Town of Opatija, Benedictines, Augustinian monastery of St Jerome in Rijeka, Jesuit College in Rijeka, Collegiate Chapter at Rijeka.

\footnotetext{
${ }^{65}$ Marko MEDVED, »Crkvene prilike u Opatiji za vrijeme talijanske uprave«, Opatijske crkvene obljetnice, str. 67-74.

${ }^{66}$ V. MUNIĆ, »Crkveni ansambl sv. Jakova u Opatiji s posebnim osvrtom na proširenje crkve iz 1940.«, Opatijske crkvene obljetnice, str. 85-90.

${ }^{67}$ I. OSTOJIĆ, Benediktinci u Hrvatskoj, sv. 3, str. 181-183.
} 